\title{
PERTUMBUHAN KULTUR TUNAS AKSILAR KENTANG (Solanum tuberosum L.) DENGAN PENAMBAHAN SUPER FOSFAT DAN KNO \\ PADA MEDIA AB MIX SECARA IN VITRO
}

\author{
Hamami Alfasani Dewanto*, Desi Saraswati, Oetami Dwi Hadjoeningtijas \\ Fakultas Pertanian, Universitas Muhammadiyah Purwokerto \\ *) sanidewanto@gmail.com
}

\begin{abstract}
Murashige \&Skoog-based medium Potatoes are one commodity that has the potential to be developed as a resource in the context of food diversification, farmers' income riser, non fossil export commodities and raw materials for processing industry. The objective of this research was to find out the effect of SP-36 fertilizer, $\mathrm{KNO}_{3}$ fertilizer, as well as the interaction between the two fertilizers on the growth of potato nodal culture on $A B$ Mix media in vitro. The results of this study are expected to provide economical potato tissue culture media development. This research used factorial complete randomized design. The treatment were SP-36 concentration: 0 ppm; 50 ppm; 100 ppm; and 200 ppm, in combination with KNO3 concentration: 0 ppm; 100 ppm; 200 ppm; 400 ppm; and 600 ppm, The variables observed included number of leaves, leaf color, length of plantlets, fresh weight of plantlets and percentage of plantlets growth. Based on the results of the analysis of variance (ANOVA) F. Calculate < F. Table with the average success of plantlet growth between 87.5-100\%. In addition, there are four types of leaf color produced, namely the color of yellowish green, pale green leaves, green, and dark green. Research showed that the interaction between SP-36 fertilizer and KNO3 fertilizer on AB Mix media had no significant effect on all observed variables.
\end{abstract}

Keywords: $A B$ Mix , $S P-36, \mathrm{KNO}_{3}$, Axiler Shoot, Solanum tuberosum.

\section{PENDAHULUAN}

Kentang termasuk salah satu komoditas tanaman hortikultura terpenting di dunia setelah padi, gandum, dan jagung. Selain itu, kentang merupakan salah satu komoditas yang mempunyai potensi untuk dikembangkan sebagai sumber karbohidrat dalam rangka menunjang program diversifikasi pangan, meningkatkan pendapatan petani, komoditas ekspor non migas dan bahan baku industri olahan (Hartuti dan Sinaga, 1998).

Media yang paling umum dipakai dalam produksi planlet kentang secara in vitro adalah media Murashige\&Skoog. Namun media ini memiliki beberapa kelemahan seperti relatif mahal dan pada pertumbuhan planlet kentang seringkali merkadi kematian pucuk (die back) dan menghasilkan tunas aksilar yang masif. Nutrisi AB mix merupakan nutrisi yang umumnya digunakan untuk budidaya tanaman dengan teknik hidroponik dengan formulasi yang berasal dari garamgaram mineral sehingga mengandung unsurunsur yang dibutuhkan tanaman untuk pertumbuhan dan perkembangannya. Nutrisi AB Mix memiliki 16 kandungan unsur hara yang terbagi menjadi dua bagian, yaitu unsur hara makro adalah unsur yang dibutuhkan dalam jumlah banyak, terdiri dari 6 unsur diantaranya adalah $\mathrm{N}, \mathrm{P}, \mathrm{K}, \mathrm{Ca}, \mathrm{Mg}$, dan $\mathrm{S}$. Selanjutnya unsur hara mikro yaitu unsur hara yang dibutuhkan dalam jumlah sedikit, terdiri 
dari 10 unsur diantaranya adalah Fe, Mn, Bo, $\mathrm{Cu}, \mathrm{Zn}, \mathrm{Mo}, \mathrm{Cl}, \mathrm{Si}, \mathrm{Na}, \mathrm{Co}$. Namun dengan kelengkapan unsur tersebut, tanamam kentang adalah tanaman yang kurang efektif memanfaatkan fosfor ditanah dan membutuhkan ketersediaan kalium yang cukup tinggi, oleh karena itu perlu untuk menambah ketersesiaan sumber fosfat dan kalium dengan penambahan SP36 dan $\mathrm{KNO}_{3}$

Berdasarkan uraian diatas, penelitian ini bertujuan untuk mengetahui pengaruh pupuk SP-36 dan $\mathrm{KNO}_{3}$ serta interaksinya pada media $\mathrm{AB}$ mix terhadap pertumbuhan kultur tunas nodus kentang varietas granola.

\section{METODE PENELITIAN}

Bahan yang digunakan meliputi eksplan kentang varietas Granola berasal dari Balai Penelitian Tanaman Sayuran Kecamatan Lembang, Kabupaten Bandung Barat yang telah berumur sekitar satu setengah bulan. Rancangan penelitian yang digunakan adalah Rancangan Acak Lengkap (RAL) faktorial yang terdiri atas dua kombinasi faktor perlakuan seperti yang ditunjukkan Tabel 3.1. Eksplan berupa tunas nodus ditanam pada botol kaca $12 \mathrm{~cm}$ dengan media dasar $\mathrm{AB}$ mix 1500 ppm. Eksplan kemudian diinkubasi pada ruang kultur dengan penyinaran lampu TL selama 16 jam/hari pada suhu $20^{\circ} \mathrm{C}$. Pemanenan dilakukan pada usia planlet 6 minggu setelah tanam (MST). Pengukuran panjang dilakukan menggunakan penggaris dari titik awal pertumbuhan tunas sedangkan pengukuran berat menggunakan timbangan digital dengan ketelitian dua desimal.

Data yang diperoleh dari hasil penelitian ditabulasikan, kemudian dianalisa dengan menggunakan uji sidik ragam untuk mengetahui perbedaan antar perlakuan, apabila perbedaan nyata $\mathrm{F}$ dihitung $>\mathrm{F}$ tabel $(5 \%)$ dilakukan uji BNT dengan taraf 5\%. Dengan variabel yang diamati berupa jumlah daun, warna daun, panjang planlet, berat basah planlet dan keberhasilan pertumbuhan planlet.

Tabel 3.1. Kombinasi Perlakuan Pupuk SP-36 dan Pupuk $\mathrm{KNO}_{3}$

\begin{tabular}{|r|c|c|c|c|}
\hline \multirow{2}{*}{ KNO3 } & \multicolumn{4}{|c|}{ SP-36 } \\
\cline { 2 - 5 } & $\mathbf{0} \mathbf{p p m}$ & $\mathbf{5 0} \mathbf{~ p p m}$ & $\mathbf{1 0 0} \mathbf{~ p p m}$ & $\mathbf{2 0 0} \mathbf{~ p p m}$ \\
\hline $\mathbf{0} \mathbf{~ p p m}$ & S0K0 & S1K0 & S2K0 & S3K0 \\
\hline $\mathbf{1 0 0} \mathbf{p p m}$ & S0K1 & S1K1 & S2K1 & S3K1 \\
\hline $\mathbf{2 0 0} \mathbf{~ p p m}$ & S0K2 & S1K2 & S2K2 & S3K2 \\
\hline $\mathbf{4 0 0} \mathbf{~ p p m ~}$ & S0K3 & S1K3 & S2K3 & S3K3 \\
\hline $\mathbf{6 0 0} \mathbf{p p m}$ & S0K4 & S1K4 & S2K 4 & S3K4 \\
\hline
\end{tabular}




\section{HASIL DAN PEMBAHASAN}

Secara umum berdasarkan hasil analisis data pada uji ANOVA menunjukkan bahwa perlakuan dan interaksi antara pupuk SP-36 dan pupuk $\mathrm{KNO}_{3}$ pada media $\mathrm{AB}$ Mix tidak berpengaruh nyata pada variabel jumlah daun, panjang planlet, bobot basah planlet dan keberhasilan pertumbuhan planlet kentang.

Tabel 4.1.2 Rangkuman Nilai Rata-rata Pertumbuhan Kultur Tunas Nodus Kentang (Solanum tuberosum L.) dengan Menggunakan SP-36 dan $\mathrm{KNO}_{3}$ pada Media AB Mix secara In Vitro (6 mst).

VARIABEL PENGAMATAN

\begin{tabular}{ccccc}
\cline { 2 - 4 } PERLAKUAN & $\begin{array}{c}\text { Jumlah } \\
\text { Daun } \\
(\text { helai })\end{array}$ & $\begin{array}{c}\text { Panjang } \\
\text { Planlet } \\
(\mathbf{c m})\end{array}$ & $\begin{array}{c}\text { Bobot Basah } \\
\text { Planlet } \\
\text { (gram) }\end{array}$ & $\begin{array}{c}\text { Keberhasilan } \\
\text { Pertumbuhan Planlet }\end{array}$ \\
\hline
\end{tabular}

Konsentrasi SP-36

$\begin{array}{lcccc}\text { S0 } & 11,72 & 10,73 & 0,10 & 97,50 \\ \text { S1 } & 12,58 & 11,57 & 0,10 & 100 \\ \text { S2 } & 11,50 & 10,44 & 0,09 & 92,50 \\ \text { S3 } & 13,19 & 10,86 & 0,13 & 97,50 \\ \text { NT 5\% } & \text { tn } & \text { tn } & \text { tn } & \text { tn }\end{array}$

Konsentrasi $\mathrm{KNO}_{3}$

K0

K1

$\mathrm{K} 2$

K3

K4

BNT 5\%

Interaksi SP-36 dan $\mathrm{KNO}_{3}$

SOKO

S1K0

S2K0

S3K0

S0K1

S1K1

S2K1

S3K1

S1K2

S1K2

S2K2

S3K2

S0K3

S1K3

S2K3

S3K3

S0K4

S1K4

S2K4

S3K4

Bnt 5\%

\section{1,96}

12,41

11,97

13,26

11,64

tn

11.00

12.63

10.25

13.96

13.50

12.38

12.00

11.75

11.75

11.88

12.63

11.63

11.00

13.25

11.67

17.13

11.33

12.75

10.96

11.50

tn

11,13
11,46
9,88
11,34
10,69
tn

8.45

12.24

10.45

13.40

13.44

12.49

11.20

8.71

10.23

9.83

9.83

9.64

10.06

12.26

10.95

12.08

11.48

11.04

9.75

10.49

tn

\section{0,13}

0,12

0,10

0,10

0,08

tn

0.08

0.10

0.10

0.25

0.15

0.11

0.14

0.08

0.10

0.12

0.09

0.09

0.10

0.10

0.07

0.13

0.06

0.08

0.07

0.11

tn
93,75

100

100

96,88

93,75

tn

100

100

87,50

87,50

100

100

100

100

100

100

100

100

100

100

87,50

100

87,50

100

87,50

100

tn 
Jumlah daun merupakan pertumbuhan tanaman yang sering diamati sebagai salah satu indikator data penunjang untuk menjelaskan proses pertumbuhan tanaman (Sitompul dan Guritno, 1995). Daun adalah salah satu organ penting bagi tumbuhan dan biasanya berwarna hijau, tumbuh dari batang, serta berperan sebagai penangkap energi dari cahaya matahari melalui fotosintesis. Semakin banyak jumlah daun yang tumbuh, maka pertumbuhan eksplan akan semakin baik. Adapun rerata jumlah daun planlet kentang berumur 6 minggu setelah tanam yang disajikan dalam Gambar 1.

Berdasarkan Gambar 1. planlet dalam setiap perlakuan mampu menghasilkan daun dengan jumlah yang relatif sama. Hal tersebut diduga karena setiap media mengandung nitrogen yang berasal dari nutrisi $\mathrm{AB}$ Mix. Unsur hara nitrogen merupakan salah satu unsur hara yang sangat dibutuhkan oleh tanaman dalam fase pertumbuhan vegetatif, salah satunya pada bagian daun. Menurut Azzam (2017) nutrisi AB mix mengandung 9,90\% $\mathrm{NO}_{3}$ dan $0,48 \% \mathrm{NH}_{4}$ sehingga nutrisi tersebut dapat merangsang pembentukan daun. Unsur nitrogen dapat mendorong perkembangan dan pertumbuhan organ-organ yang berkaitan dengan fotosintesis, yaitu daun. Selain nitrogen, adanya kandungan Amonium pada nutrisi $\mathrm{AB}$ Mix tersebut diduga ikut berperan dalam merangsang pembentukan tunas sehingga planlet akan menghasilkan daun. Menurut Hyndman et al., (1982) Amonium dapat meningkatkan biosintesis sitokinin alami yang berfungsi untuk menstimulasi pertunasan.

Pemberian pupuk SP-36 yang cukup, dapat menjaga kualitas daun tetap baik. Jika tanaman mengalami defisiensi unsur $\mathrm{P}$, maka bentuk daun menjadi tidak normal dan bagian-bagian daun menjadi mati. Selain itu, pemberian pupuk $\mathrm{KNO}_{3}$ dengan jumlah yang cukup, dapat mempengaruhi terbentuknya daun.

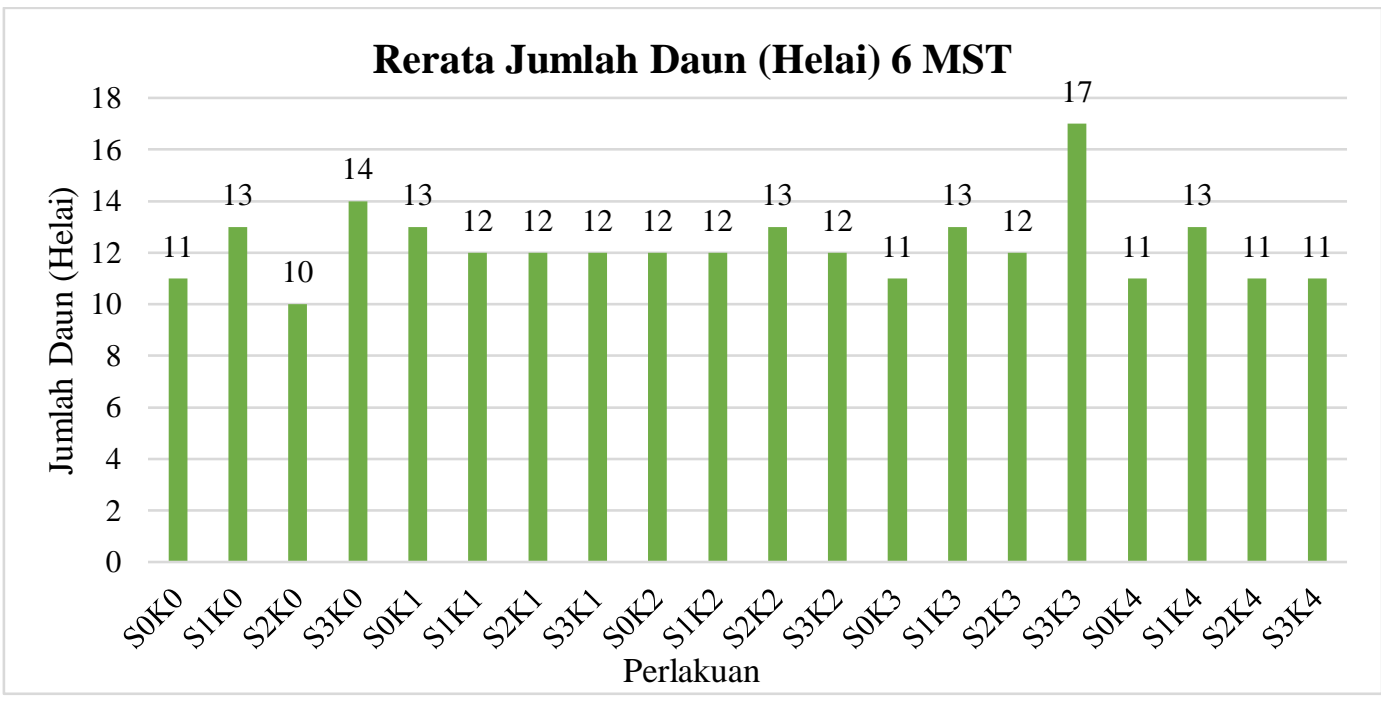

Gambar 1. Rerata Jumlah Daun 
Selain unsur nitrogen, unsur kalium dapat berperan dalam pembentukan daun. Menurut Perrenound (1993) kekurangan kalium pada tanaman kentang dapat menghambat terbentuknya daun sehingga akan mempengaruhi proses fotosintesis yang terjadi di bagian daun. Dari penelitian ini dapat disimpulkan bahwa penambahan fosfat dan kalium pada media AB Mix tidak memberikan pengaruh yang nyata pada variabel jumlah daun. Penambahan SP-36 dan pupuk $\mathrm{KNO}_{3}$ tidak mengganggu pembentukan daun pada planlet kentang.

Selain jumlah daun, warna yang ditimbulkan pada daun dalam setiap perlakuan rata-rata mendapatkan warna daun yang sedikit berbeda yaitu berwarna hijau pucat, hijau cerah, hijau tua, dan hijau kekuningan. Warna hijau pada daun kentang disebabkan karena terbentuknya klorofil yang berasal dari unsur nitrogen (N), Magnesium (Mg), dan Mangan (Mn). Nitrogen merupakan unsur penyusun klorofil, sedangkan Magnesium dan Mangan merupakan bagian dari klorofil. Berdasarkan hasil pengamatan, pada perlakuan SOK0 (Kontrol), S1K0 (50 ppm SP-36), S2K0 (100 ppm SP-36), S3K0 (200 ppm SP-36), dan S3K1 (200 ppm SP-36 + 100 ppm $\left.\mathrm{KNO}_{3}\right)$ mendapatkan daun berwarna hijau pucat..

Tabel 2. Warna Daun Pada Eksplan

\begin{tabular}{lcccc}
\hline & \multicolumn{4}{c}{ Warna Daun } \\
\cline { 2 - 5 } Perlakuan & $\begin{array}{c}\text { Hijau } \\
\text { Pucat }\end{array}$ & Hijau & $\begin{array}{c}\text { Hijau } \\
\text { Tua }\end{array}$ & $\begin{array}{c}\text { Hijau } \\
\text { Kekuningan }\end{array}$ \\
\hline S0K0 & $\sqrt{ }$ & - & - & $\sqrt{ }$ \\
S1K0 & $\sqrt{ }$ & - & - & $\sqrt{ }$ \\
S2K0 & $\sqrt{ }$ & - & - & $\sqrt{ }$ \\
S3K0 & $\sqrt{ }$ & - & - & $\sqrt{ }$ \\
S0K1 & - & $\sqrt{ }$ & - & - \\
S1K1 & - & $\sqrt{ }$ & - & - \\
S2K1 & - & $\sqrt{ }$ & - & - \\
S3K1 & $\sqrt{ }$ & - & - & $\sqrt{ }$ \\
S0K2 & - & $\sqrt{ }$ & $\sqrt{ }$ & - \\
S1K2 & - & $\sqrt{ }$ & $\sqrt{ }$ & - \\
S2K2 & - & $\sqrt{ }$ & - & - \\
S3K2 & - & $\sqrt{ }$ & - & - \\
S0K3 & - & $\sqrt{ }$ & $\sqrt{ }$ & - \\
S1K3 & - & $\sqrt{ }$ & $\sqrt{ }$ & - \\
S2K3 & - & - & $\sqrt{ }$ & - \\
S3K3 & - & $\sqrt{ }$ & - & - \\
S0K4 & - & $\sqrt{ }$ & $\sqrt{ }$ & - \\
S1K4 & - & $\sqrt{ }$ & $\sqrt{ }$ & - \\
S2K4 & - & $\sqrt{ }$ & $\sqrt{ }$ & - \\
S3K4 & - & - & $\sqrt{ }$ & - \\
\hline
\end{tabular}


Berdasarkan data tersebut perlakuan yang mendapatkan daun berwarna hijau pucat adalah perlakuan yang hanya diberi pupuk SP36, karena kandungan $\mathrm{N}$ yang terdapat di dalam media tersebut hanya berasal dari nutrisi AB Mix. Sehingga diduga bahwa nutirisi AB Mix dengan konsentrasi 1500 ppm memberikan daun planlet kentang berwarna hijau pucat. Selain itu, dengan kandungan fosfor berlebih dapat menyebabkan penyerapan unsur hara nitrogen berkurang karena terjadi ikatan-ikatan kimia antara $\mathrm{P}$ dan $\mathrm{N}$, seperti daun menjadi pucat, layu, dan kering.

Sedangkan pada perlakuan S0K2 (200 ppm $\mathrm{KNO}_{3}$ ), S1K2 (50 ppm SP-36 + 200 ppm $\mathrm{KNO}_{3}$ ), S0K3 (400 ppm $\left.\mathrm{KNO}_{3}\right), \mathrm{S} 1 \mathrm{~K} 3(50$ ppm sp-36 + 400 ppm $\mathrm{KNO}_{3}$ ), S2K3 (100 PPM SP-36 + 400 ppm $\mathrm{KNO}_{3}$ ), S0K4 (600 ppm $\mathrm{KNO}_{3}$ ), S1K4 (50 ppm SP-36 + 600 ppm $\mathrm{KNO}_{3}$ ), S2K4 (100 PPM SP-36 + 600 PPM $\mathrm{KNO}_{3}$ ), dan S3K4 (200 PPM SP-36 + 600
PPM $\mathrm{KNO}_{3}$ ) mendapatkan warna daun yang lebih tua. Hal tersebut diduga karena penambahan unsur $\mathrm{N}$ yang berasal dari pupuk $\mathrm{KNO}_{3}$ sehingga warna daun yang dihasilkan lebih gelap. Menurut Aisyah (2013), semakin hijau warna daun pada suatu tanaman, maka semakin tinggi pula kandungan klorofil dalam daun tersebut.

Selanjutnya pada perlakuan SOK0, (kontrol), S1K0 (50 ppm SP-36), S2K0 (100 ppm SP-36), S3K0 (200 ppm SP-36), dan S3K1 (200 ppm SP-36 + 100 ppm $\mathrm{KNO}_{3}$ ) mendapatkan daun berwarna hijau kekuningan. Warna kekuningan pada daun planlet kentang diduga karena pengaruh dari pemberian unsur hara fosfor yang berlebih. Kelebihan unsur hara fosfor dapat menyebabkan penyerapan unsur hara nitrogen berkurang karena terjadinya ikatan-ikatan kimia antara $\mathrm{P}$ dan $\mathrm{N}$, sehingga menyebabkan daun menjadi pucat,

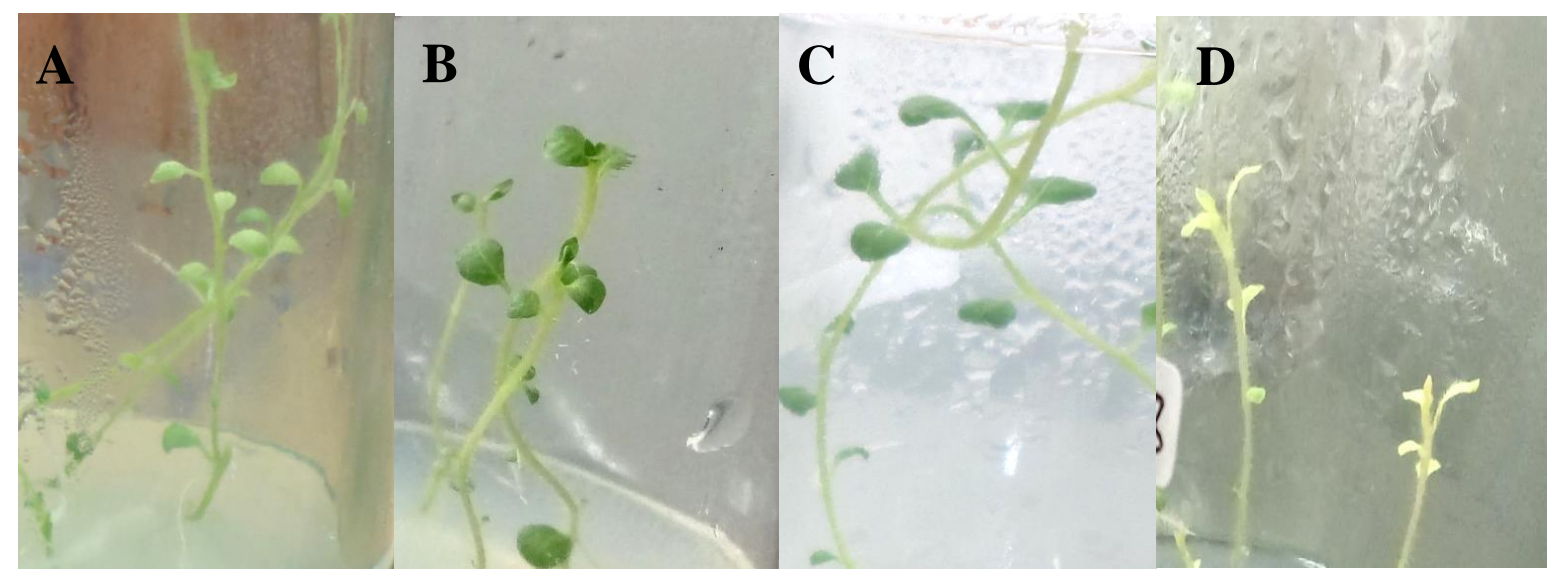

Gambar 2. Perbedaan Warna Daun, A. Daun berwarna hijau pucat, B. Daun berwarna hijau cerah, C. Daun berwarna hijau tua.D. Daun berwarna hijau kekuningan 
layu dan kering serta dapat menimbulkan perubahan warna daun menjadi kuning akibat kurang terserapnya unsur hara nitrogen.

Dari kurang terserapnya unsur nitrogen tersebut akan mempengaruhi warna pada daun. Sedangkan menurut Batchelor (1981) bahwa daun yang tampak berwarna kuning atau klorosis dapat disebabkan karena kurang terserapnya unsur nitrogen.

Pertumbuhan merupakan suatu proses pertambahan ukuran, baik bobot, volume, serta jumlah sel yang bersifat irreversible (tidak dapat kembali ke asal). Selain jumlah daun, tinggi tanaman merupakan pertumbuhan tanaman yang sering diamati sebagai salah satu indikator untuk menjelaskan proses pertumbuhan tanaman (Sitompul dan Guritno,
1995). Menurut Heddy (1991) terjadinya penambahan tinggi planlet disebabkan oleh dua proses yaitu pembelahan dan pemanjangan sel. Kedua proses tersebut terjadi pada jaringan meristem.

Berdasarkan hasil analisis data pada uji ANOVA menunjukkan bahwa interaksi antara SP-36 dan $\mathrm{KNO}_{3}$ pada media AB Mix tidak berpengaruh nyata terhadap variabel panjang planlet kentang. Hal ini diduga bahwa nutrisi AB Mix dengan konsentrasi 1500 ppm telah memenuhi kebutuhan hara planlet kentang sehingga panjang planlet yang dihasilkan tidak jauh berbeda dengan panjang planlet yang diberi perlakuan pupuk SP-36 dan pupuk $\mathrm{KNO}_{3}$. Namun rerata panjang planlet pada setiap perlakuan mendapatkan hasil berbeda (Gambar 3).

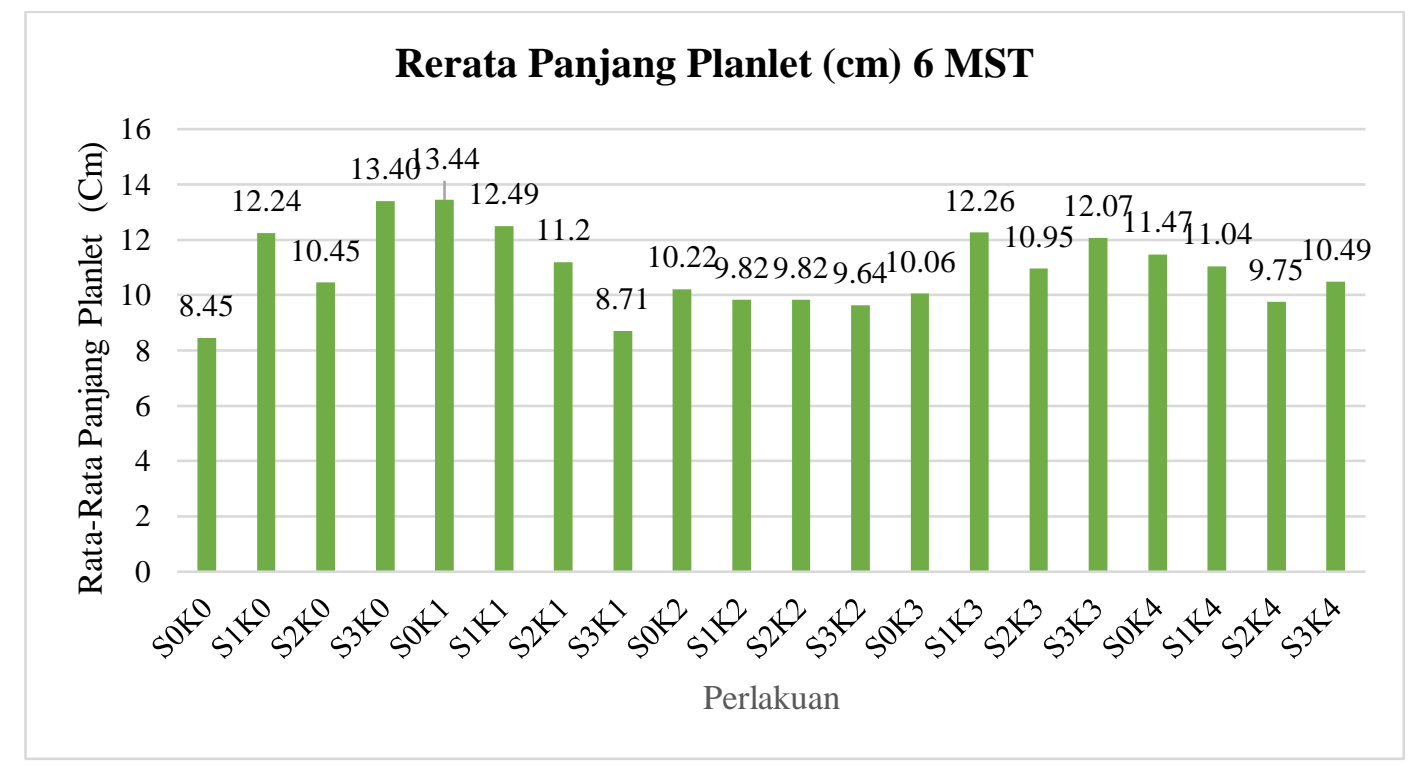

Gambar 3 Rerata Panjang Planlet

Berdasarkan hasil penelitian, setiap eksplan pada semua perlakuan mengalami pertumbuhan batang yang semakin hari semakin panjang. Menurut Gardner, et all 
(1991) pertumbuhan panjang batang terjadi di dalam meristem interkalar dari ruas. Ruas memanjang sebagai akibat meningkatnya jumlah sel dan meluasnya sel. Pertumbuhan batang eksplan terjadi karena sel mengalami pembelahan pada dasar ruas bukan pada meristem ujung.

Pemberian pupuk $\mathrm{KNO}_{3}$ yang cukup, dapat mempengaruhi pertumbuhan panjang eksplan kentang dimana $\mathrm{KNO}_{3}$ mengandung unsur Kalium dan Nitrogen sekaligus. Kalium berperan dalam pengaturan osmotik sel. Pengaturan potensial osmotik sel berpengaruh terhadap tekanan turgor sel sehingga dapat meingkatkan pemanjangan sel yang ditunjukkan secara visual, salah satunya oleh tinggi/panjang planlet kentang. Selain itu, unsur nitrogen berperan dalam pertumbuhan panjang planlet. Menurut Noggle dan Fritz (1983) nitrogen berperan sebagai komponen penyusun hormon auksin yang berfungsi sebagai pembelahan dan pemanjangan sel. Pemberian auksin akan meningkatkan pemanjangan sel ke arah vertikal, sehingga dapat meningkatkan tinggi tanaman.

Selain itu, pupuk SP-36 dengan jumlah yang cukup, dapat mempengaruhi pertumbuhan panjang planlet kentang. Menurut Parman (2007) fosfor memiliki peran penting sebagai ATP dalam semua proses metabolisme tanaman kentang, seperti fotosintesis, respirasi, dan pembelahan serta pemanjangan sel. Peningkatan peran ATP dalam semua proses tersebut dapat meningkatkan pertumbuhan tanaman kentang yang secara visual dapat dilihat dari tinggi/panjang tanaman, jumlah daun, dan panjang akar. Selain itu, fosfor sebagai penyusun ATP-ase dapat memberikan pengaruh positif karena dapat meningkatkan tekanan turgor sel, sehingga terjadi pemanjangan sel. Pemanjangan sel dapat diketahui berdasarkan tinggi/panjang tanaman dan panjang akar.

Selain pengaruh dari perlakuan pupuk, pertumbuhan planlet kentang dapat dipengaruhi oleh kondisi dari eksplan tersebut. Pertumbuhan planlet kerdil kemungkinan disebabkan karena ketidaknormalan pertumbuhan planlet baik secara morfologi maupun fisiologis akibat stres karena adanya pelukaan ketika penanaman.

Aktivitas metabolisme dan nilai berat basah tanaman yang dipengaruhi oleh unsur hara, kandungan air jaringan, serta hasil metabolisme dapat ditunjukan oleh berat basah tanaman (Salisbury et al, 1995). Berdasarkan hasil analisis data pada uji ANOVA (Lampiran 3) menunjukkan bahwa interaksi antara SP-36 dan $\mathrm{KNO}_{3}$ pada media $\mathrm{AB}$ Mix memberikan hasil yang tidak berbeda nyata. Hal tersebut diduga bahwa nutrisi AB Mix dengan konsentrasi 1500 ppm telah memenuhi kebutuhan hara planlet kentang sehingga bobot basah planlet yang dihasilkan tidak jauh berbeda dengan bobot basah planlet yang diberi perlakuan pupuk SP-36 dan pupuk $\mathrm{KNO}_{3}$. Selain itu adanya kandungan vitamin $\mathrm{B}$ 
kompleks dalam media diduga dapat mempengaruhi bobot basah planlet tersebut, karena vitamin B kompleks mengandung Thiamine $\mathrm{HCl}$, Riboflavinum, Pyridoxine $\mathrm{HCl}$, Calcium Pantothenas, dan Nicorinamidum. Menurut Hendaryono dan Wijayani (2012) vitamin seperti tiamin berperan sebagai koenzim dalam reaksi yang menghasilkan energi dari karbohidrat. Selain itu, tiamin dapat mempercepat pembelahan sel pada bagian sel meristem akar, sehingga akar tersebut akan melakukan penyerapan air dan hara pada media yang dapat mempengaruhi bobot basah pada planlet. Adapun hasil rerata bobot basah planlet kentang pada setiap perlakuan memiliki hasil yang berbeda (Gambar 4.2.5.1).

Menurut Indah dan Dini (2016) bahwa bobot basah pada tanaman secara fisiologi terdiri dari dua kandungan yaitu air dan karbohidrat. Meningkatnya jumlah daun serta tinggi tanaman akan mempengaruhi berat basah tanaman. Bertambahnya bobot basah planlet tidak terlepas dari peran akar, dimana akar berfungsi untuk menyerap air dan unsur hara di dalam media sehingga dapat mempengaruhi bobot basah planlet. Pemberian pupuk SP-36 yang cukup sangat berperan dalam merangsang pertumbuhan akar sehingga akar yang dihasilkan dapat menyerap air dan unsur hara dalam media. Hal tersebut sesuai dengan pernyataan Marzuki (2007) bahwa unsur fosfor dapat merangsang pertumbuhan akar. Selain itu, pemberian pupuk $\mathrm{KNO}_{3}$ yang cukup akan mempengaruhi bobot basah planlet. Menurut Gunarto (2003), jika pupuk $\mathrm{KNO}_{3}$ diberikan dalam jumlah tinggi ataupun rendah akan mengakibatkan terganggunya pengaturan osmotik sel. Kondisi ini memungkinkan terjadinya plasmolisis yang ditandai oleh keluarnya cairan dari dalam sel karena tertarik oleh larutan hara yang lebih pekat. Oleh karena itu, tekanan turgor sel akan menurun, sehingga pemanjangan sel terhambat dan secara visual dapat dilihat pada rendahnya tinggi tanaman, jumlah daun, dan panjang akar, sehingga dapat mempengaruhi bobot basah planlet. Selain itu menurut Fageria (2009) bahwa pertumbuhan tanaman akan terhambat serta penyerapan unsur kalsium akan tertekan karena pemberian unsur kalium dalam jumlah banyak. Sehingga dampak dari pemberian unsur kalium yang berlebih tersebut, kemungkinan dapat mempengaruhi bobot basah eksplan kentang.

Pertumbuhan suatu tanaman dapat dilihat dari ukuran panjang, lebar atau luas, serta pertambahan massa atau berat (Bidwell, 1979). Berdasarkan hasil analisis data pada uji ANOVA (Lampiran 4) menunjukkan bahwa interaksi antara pupuk SP-36 dan pupuk $\mathrm{KNO}_{3}$ pada media $\mathrm{AB}$ Mix memberikan hasil tidak berpengaruh nyata pada keberhasilan pertumbuhan planlet kentang. Hal tersebut diduga bahwa nutrisi AB Mix dengan konsentrasi 1500 ppm memenuhi kebutuhan hara planlet kentang sehingga jumlah pertumbuhan planlet yang dihasilkan tidak jauh berbeda pada setiap perlakuannya. Hasil 
rerata keberhasilan pertumbuhan planlet kentang berkisar antara 87,5\% - 100\% (Tabel $3)$.

Tabel.3. Persentase Keberhasilan Pertumbuhan Planlet

\begin{tabular}{ccc}
\hline Perlakuan & $\begin{array}{c}\text { Persentase } \\
\text { Keberhasilan }\end{array}$ & $\begin{array}{c}\text { Kategori } \\
\text { Keberhasilan }\end{array}$ \\
\hline S0K0 & $100 \%$ & Sangat Baik \\
S1K0 & $100 \%$ & Sangat Baik \\
S2K0 & $87.5 \%$ & Baik \\
S3K0 & $87.5 \%$ & Baik \\
S0K1 & $100 \%$ & Sangat Baik \\
S1K1 & $100 \%$ & Sangat Baik \\
S2K1 & $100 \%$ & Sangat Baik \\
S3K1 & $100 \%$ & Sangat Baik \\
S0K2 & $100 \%$ & Sangat Baik \\
S1K2 & $100 \%$ & Sangat Baik \\
S2K2 & $100 \%$ & Sangat Baik \\
S3K2 & $100 \%$ & Sangat Baik \\
S0K3 & $100 \%$ & Sangat Baik \\
S1K3 & $100 \%$ & Sangat Baik \\
S2K3 & $87.5 \%$ & Baik \\
S3K3 & $100 \%$ & Sangat Baik \\
S0K4 & $87.5 \%$ & Baik \\
S1K4 & $100 \%$ & Sangat Baik \\
Saik & $87.5 \%$ & \\
Sangat Baik
\end{tabular}

Berdasarkan tabel 4.2.6.1 menghasilkan dua jenis keberhasilan yang berbeda. Perlakuan S0K0, S1K0, S0K1, S1K1, S2K1, S3K1，S0K2，S1K2，S2K2，S3K2，S0K3, S1K3, S3K3, S1K4, dan S3K4 termasuk ke dalam tingkat keberhasilan pertumbuhan yang sangat baik yaitu $100 \%$. Sedangkan pada perlakuan S2K0, S3K0, S2K3, S0K4, dan S2K4 termasuk kedalam tingkat keberhasilan pertumbuhan yang baik yaitu $87,55 \%$. Terjadinya perbedaan tingkat keberhasilan pada perlakuan tersebut disebabkan karena terdapat eksplan yang tidak mampu untuk tumbuh dan berkembang sehingga eksplan mengalami kematian. Eksplan yang tidak mampu untuk tumbuh tersebut kemungkinan mati pada saat awal penanaman. Eksplan yang mengalami kematian terdapat pada perlakuan S2K0 (100 ppm SP-36), S3K0 (200 ppm SP36), S2K3 (100 ppm SP-36 + 400 ppm $\mathrm{KNO}_{3}$ ), S0K4 (600 ppm $\left.\mathrm{KNO}_{3}\right)$, dan S2K4 (100 ppm SP-36 + 600 ppm $\mathrm{KNO}_{3}$ ). Matinya eksplan tersebut diduga karena ketidaknormalan pertumbuhan planlet baik secara morfologi maupun fisiologis akibat stres karena adanya pelukaan ketika penanaman.

\section{KESIMPULAN}

Berdasarkan hasil penelitian yang telah dilakukan, maka dapat disimpulkan sebagai berikut:

1. Pengaruh pemberian pupuk SP-36 tidak berpengaruh nyata terhadap pertumbuhan kultur tunas nodus kentang pada semua variable pengamatan meliputi jumlah daun, 
tinggi planlet, berat basah, dan keberhasilan pertumbuhan planlet.

2. Pengaruh pemberian pupuk $\mathrm{KNO}_{3}$ tidak berpengaruh nyata terhadap pertumbuhan kultur tunas nodus kentang pada semua variable pengamatan meliputi jumlah daun, tinggi planlet, berat basah, dan keberhasilan pertumbuhan planlet.

3. Interaksi pupuk SP-36 dan pupuk $\mathrm{KNO}_{3}$ pada media $\mathrm{AB}$ Mix tidak berpengaruh nyata terhadap pertumbuhan kultur tunas nodus kentang pada semua variabel pengamatan meliputi jumlah daun, tinggi planlet, berat basah, dan keberhasilan pertumbuhan planlet.

\section{DAFTAR PUSTAKA}

Azzam. 2017. Pengaruh Komposisi Nutrisi Hidroponik.

http://www.azzamrumahherbal.com/hid roponik/226-cara-menanam-

hidroponik-menggunakan-nutrisi-

hidroponik-ab-mix.html?start $=1$.

Diakses pada 28 April 2018.

Batchelor, P.S. 1981. Orchid Culture Watering. Journal Amer Orchid Soc. 50 (8): 945-952.

Bidwell, R.G.S. 1979. Plant Physiology. Mac Millan Publishing Co.Inc. New York.

Fageria, N. K. 2009. Nutrient Uptake in Crop Plants. Boca Raton, FL: CRC Press.

Gardner. 1991. Fisiologi Tanaman Budidaya. UI Press. Jakarta

Gunarto, A. 2003. Pengaruh Penggunaan Ukuran Bibit Terhadap Pertumbuhan, Produksi dan Mutu Umbi Kentang Bibit G 4 (Solanum tuberosum L.). Jurnal Sains dan Teknologi Indonesia. 5 (5) : 173 - 179.

Hartuti,. N dan Sinaga,. RM. 1998. Kripik Kentang salah satu Diversifikasi
Produk. Balai Penelitian Tanaman Sayuran. Lembang.

Heddy. 1991. Hormon Tumbuh. CV Rajawali. Jakarta. 97 p.

Hendaryono, D. P. S., dan Wijayani, A. 2012. Teknik Kultur Jaringan. Kartisius. Yogyakarta.

Hyndman, S.L, P.M Hasegawa, and K.A. Bressand. 1982. Stimulation of root initiation from cultured rose through the use concentration of mineral salt. Hort. Sci. 17(1):82-83.

Indah, P., dan Dini. 2011. Induksi Kalus Daun Nyamplung (calophyllum inophyllum Linn.) pada Beberapa Kombinasi Kosentrasi 6benzylaminopurine (BAP) dan 2,4Dichorophenoxyacetic Acid (2,4-D). Jurnal Sains dan Seni Pomits 2 (1) : 2337 -3520 .

Marzuki, R. 2007. Bertanam Kacang Tanah. Penebar Swadaya. Jakarta.

Noggle, G.R. and G.J. Fritz. 1983. Introductory Plant Physiologi. New Jersey: Prentice-Hall, Inc.

Parman, S. 2007. Pengaruh Pemberian Pupuk Organik Cair terhadap Pertumbuhn dan Produksi Kentang (Solanum tuberosum L.).Buletin Anatomi dan Fisiologi27 (2) :26.

Perrenound, S. 1993. Fertilizing for higher yield potato. IPI Bull. No. 8. 2 nd Ed. International Potash Institute, Berne, Switzerland.

Sitompul, S. M. dan Guritno, B. 1995. Pertumbuhan Tanaman. UGM Press. Yogyakarta. 